\title{
ПРИРОДНІ ТА ПРЕФОРМОВАНІ ФІЗИЧНІ ФАКТОРИ ЯК СКЛАДОВА КОМПЛЕКСНОЇ ПРОГРАМИ САНАТОРНО-КУРОРТНОЇ РЕАБІЛІТАЦІЇ ДІТЕЙ У ПЕРІОДІ РЕМІСІЇ ОНКОЛОГІЧНИХ ЗАХВОРЮВАНЬ
}

Природні та преформовані фрізичні фактори як складова комплексної програми санаторно-курортної реабілітації дітей у періоді ремісії онкологічних захворювань

І. П. Шмакова, Г. А. Шаповалова, Д. О. Уманський Одеський національний медичний університет

Резюме. Актуальність роботи зумовлена неабиякою перспективністю нового вектора реабілітаційної медицини - санаторно-курортної реабілітації, зокрема дітей, у періоді ремісії онкологічних захворювань (ОЗ).

Мета дослідження - обгрунтувати використання природних та префрормованих фрізичних оракторів (магнітотерапії та «сухих» вуглекислих ванн) на санаторному етапі в комплексній програмі реабілітації дітей у періоді ремісії онкологічних захворювань.

Матеріали і методи. Бібліометричні, аналітичні.

Результати. Застосування лікувального комплексу з додатковим призначенням магнітотерапії (РК1) дозволяє вірогідно зменшити скарги дітей у періоді ремісії Оз із супутніми захворюваннями нервової системи. За показниками УЗД встановлено статистично вірогідні позитивні зміни мозкової гемодинаміки. Результати УЗ ЕхоЕГ свідчать про покращання ліквородинаміки. За даними ЕЕГ встановлено позитивні зміни в стані електрогенезу головного мозку. Після проведеного лікувального комплексу з додатковим призначенням «сухих» вуглекислих ванн (РК2) покращилося самопочуття дітей. За показниками ультразвукової доплерограсрії у 70,0 \% дітей нормалізувався кровообіг по черебральних артеріях. Венозна дисгемія реєструвалась удвічі рідше порівняно з вихідними даними. Венозний застій III cm. не реєструвався. Частота виявлення внутрішньочерепної гіпертензії зменшилася 3 90,0 до 50,0 \%. За показниками ультразвукової ехоенцеоралографії відмічалося покращення ліквородинаміки у вигляді зменшення індексу пульсації вдвічі та частоти реєстрації додаткових Ехо-сигналів більш ніж утричі у 70,0 \% хворих дітей. Стан електрогенезу характеризувався нормалізацією біоелектричної активності головного мозку, що супроводжувалося стабілізацією ффункціональної активності кори у 70,0% дітей.

Висновки. Результати досліджень свідчать про ефрективність фрізичних фракторів магнітотерапії та
Natural and preformed physical factors as a component of the complex program of health and spa rehabilitation of children during the period of remission of cancer diseases (Literature review and own research results)

I. P. Shmakova, H. A. Shapovalova, D. O. Umansky Odesa National Medical University

e-mail: mokienkoav56@gmail.com

Summary. The relevance of the work is due to the significant prospects of a new vector of rehabilitation medicine - sanatorium rehabilitation, in particular children, in the period of remission of oncological diseases.

The aim of the study - to substantiate the use of natural and preformed physical factors (magnetotherapy and "dry" carbon dioxide baths) at the sanatorium stage in a comprehensive program for the rehabilitation of children in remission of cancer diseases $(C D)$.

Materials and Methods. Bibliometric, analytical.

Results. The use of a medical complex with the additional appointment of magnetotherapy (RK1) can reliably reduce the complaints of children in remission of $C D$ with concomitant diseases of the nervous system. According to the US indicators, statistically significant positive changes in cerebral hemodynamics were established. The results of ultrasound echoEG indicate an improvement in CSF dynamics. According to EEG data, positive changes in the state of brain electrogenesis were established. After the treatment complex with the additional appointment of "dry" carbon dioxide baths (RK2), the health of the children improved. According to the indicators of ultrasound dopplerography, blood circulation in the cerebral arteries normalized in $70.0 \%$ of children. Venous dysgemia was recorded half as often as compared with the baseline data. Venous stasis stage III was not registered. The frequency of detection of intracranial hypertension decreased from 90.0 to $50.0 \%$. According to the indicators of ultrasound echoencephalography, there was an improvement in CSF dynamics in the form of a decrease in the pulsation index by half and the frequency of registration of additional echo signals by more than three times in $70.0 \%$ of sick children. The state of electrogenesis was characterized by the normalization of the bioelectrical activity of the brain, which was accompanied by the stabilization of the functional activity of the cortex in $70.0 \%$ of children.

Conclusions. The research results indicate the effectiveness of the physical factors of magnetotherapy and 
«сухих» вуглекислих ванн як значущих складових комплексів санаторно-курортної реабілітації дітей у періоді ремісії онкологічних захворювань.

Ключові слова: діти; онкологічні захворювання; нервова система; санаторно-курортна реабілітація; магнітотерапія; «сухі» вуглекислі ванни.

\section{ВСТУП}

Фізичні методи лікування пацієнтів із новоутвореннями спрямовані на деструкцію і загибель пухлинних клітин (онкодеструктивні методи), гальмування розвитку пухлини (цитолітичні методи), пригнічення аутоімуних процесів (імуносупресивні методи). Після оперативного видалення пухлини або хіміотерапії застосовують методи активації імунітету (імуностимулювальні методи) і корекції вегетативних розладів (вегетокоригувальні методи).

На санаторно-курортне лікування направляють пацієнтів після радикальних операцій злоякісних пухлин з повною упевненістю неможливості рецидиву пухлини і метастазів. Середній строк направлення - через 6-12 місяців після операції переважно в місцеві санаторії. що більша злоякісність пухлини, то більший інтервал між операцією і направленням на курорт. При цьому в санаторно-курортній карті повинен бути запис лікаря-онколога, на обліку в якого перебуває хворий, з рекомендацією санаторно-курортного лікування на відповідному курорті або в місцевому санаторії, із зазначенням сезону року. Таких хворих направляють на клімато- і бальнеолікувальні курорти, оскільки пелоїдотерапія їм протипоказана.

Метою дослідження було обґрунтувати використання природних та преформованих фрізичних фракторів («сухих» вуглекислих ванн та магнітотерапії) на санаторному етапі в комплексній програмі реабілітації дітей у періоді ремісії онкологічних захворювань.

\section{МАТЕРІАЛИ I МЕТОДИ}

Бібліометричні, аналітичні.

\section{РЕЗУЛЬТАТИ Й ОБГОВОРЕННЯ}

Накопичені на сьогодні результати свідчать про можливість раціонального застосування лікувальних фрізичних фракторів у різних групах онкологічних хворих.

На думку авторів [1], відновлювальна терапія онкохворих на санаторно-курортному етапі може предбачати, зокрема, різні види переважно нетеплової апаратної і неапаратної фрізіотерапії, у тому числі ізотермічні ванни, душі, гідрокінезотерапію в басейнах.

Актуальними є питання показань і протипоказань до застосування фрізичних фракторів у реабілі- "dry" carbon dioxide baths as significant components of the sanatorium-resort rehabilitation of children in the period of remission of cancer diseases.

Key words: children; cancer diseases; nervous system; spa rehabilitation; magnetotherapy; "dry" carbon dioxide baths.

тації хворих у періоді ремісії онкозахворювань. Застосування електросну в періоді ремісії онкологічних захворювань у дорослого та дитячого контингенту хворих сприяє поліпшенню нейрорегуляторних процесів, зменшенню виявів вегетативної дисфункції, психоемоційної лабільності, астеноневротичного синдрому. Обґрунтовано застосування мікрокліматотерапіі в загальному санаторному комплексі 3 метою поліпшення метаболічних процесів, системи дихального апарату, підвищення адаптаційного потенціалу [2].

До щадних чинників належать «сухі» вуглекислі ванни без гідростатичного навантаження і фрормування антистресового впливу. «Сухі» вуглекислі ванни не викликають негативних реакцій у низьких резервах серцево-судинної системи, але їх використовують тільки в умовах хоспісу в онкологічних хворих за відсутності зрушень у перифреричній крові [3-7].

Вуглекислий газ, який є одним із кінцевих продуктів метаболізму, водночас слугує важливим регулятором обміну речовин, зокрема біосинтетичних процесів. Вуглекислота $€$ важливим компонентом системи кислотно-лужного гомеостазу. Вона $€$ джерелом вуглеводню для вуглеводних структур органічних речовин і регулятором активності низки ферментів, проникності клітинних мембран для деяких метаболітів, інтенсивності фрункціонування травних та ендокринних залоз тощо. Вуглекислота зменшує загальний периферичний судинний опір, що в свою чергу знижує навантаження на серцево-судинну систему, змінює фрункціональний стан дихального центру, чинить бронхолітичний вплив, поліпшує тканинне дихання за рахунок дисоціації оксигемоглобіну та повнішого перехіду кисню у тканини, що сприяє поліпшенню метаболізму. Вуглекислоті притаманна важлива роль у нормалізації функції вегетативної нервової системи в дітей. У механізмі дії штучних «сухих» вуглекислих ванн виділяють вплив на об'ємну швидкість кровотоку в мікроциркуляторному руслі, підвищення ударного об'єму та міокардіального резерву, що сприяє зменшенню клінічних симптомів психоастеноневротичного стану, збільшенню толерантності до фрізичного навантаження й підвищенню загальної резистентності організму. Ці зміни фрормуються шляхом підвищення рівня кисню в капілярній крові та спроможності вуглекислого газу пришвидшувати процес дисоціації оксигемоглобіну та надходження кисню у кров. Взагалі необхідно визначити позитив- 
ний вплив «сухих» вуглекислих ванн на регуляцію окиснювально-відновлювальних процесів, імунну систему, стан кровообігу, що забезпечує сприятливу саногенетичну дію на організм [3-7].

Процедури «сухих» вуглекислих ванн мають антистресорну дію, сприяють зниженню психоемоційної напруги, розумового й фрізичного стомлення, ендогенної інтоксикації, що покращує самопочуття, настрій хворого і якість життя, що важливо для діей з О3. Встановлено вищу ефективність «сухих» вуглекислих ванн у дітей із симпатикотонічним типом синдрому вегетативної дисорункції. На всіх етапах медичної реабілітації дітей із синдромом вегетативної дистонії запропоновано методику лікування «сухими» вуглекислими ваннами 3 концентрацією газової суміші $25 \%$, температурою $28^{\circ} \mathrm{C}$, тривалістю процедури для дітей 9-11 років - 15 хв, 12-15 років - 20 хв, на курс 8-10 щоденних процедур [4]. Методики застосування «сухих» вуглекислих ванн у різноманітних захворюваннях можуть бути підставою для розроблення методик для дітей з ОГЗ за щадним режимом [8]. В умовах гіперкапнії одночасний розвиток вазомоторного і трофрічного ефектів судинно-рухових центрів, оптимізація кровопостачання та кисневого забезпечення тканин фрормують механізми довготривалої адаптації до стресогенних фракторів довкілля.

Застосування «сухих» вуглекислих ванн запобігає негативним моментам, які спостерігаються під час використання водних вуглекислих ванн: відсутність гідростатичного тиску, подразнювального впливу на дихальну систему, обмеження порушень терморегуляції хворого. «Сухі» вуглекислі ванни не потребують спеціальних бальнеотехнічних пристроїв та доступні в експлуатації. Перевагою цих ванн $€$ відсутність гідростатичного компонента, який $є$ небажаним щодо додаткового впливу на організм хворої дитини зі зниженням толерантності до фрізичних навантажень [5-7].

Таким чином, обґрунтуванням до застосування «сухих» вуглекислих ванн $€$ регулювання співвідношення припливу/відтоку крові за наявності дискоординації судинної та метаболічної функцій; врегулювання фрункціонування ВНС; поліпшення тканинного дихання та метаболізму за рахунок дисоціації оксигемоглобіну й оптимального переходу $\mathrm{O}_{2}$ у тканини; підвищення толерантності до фрізичного навантаження; регулювання системи кислотно-лужного гомеостазу, активності фрерментів, проникнення метаболітів через клітинні мембрани; поліпшення тросріко-пластичного обміну; уповільнення процесів деструкції та дезорганізації сполучної тканини; регулювання інтенсивності фрункціонування травних та ендокринних залоз; нормалізація імунорегулювальних процесів продукції протизапальних клітин.

Низькочастотна магнітотерапія - лікувальне застосування магнітної складової змінного елек- тромагнітного поля низької частоти. За рахунок періодичної зміни орієнтації некомпенсованих спінових магнітних моментів вільних радикалів низькочастотне магнітне поле може істотно змінювати (шляхом індукції синглет-триплетного переходу) швидкість перекисного окиснення ліпідів. Це сприяє активації трофрічних процесів в органах і тканинах, усуває інфільтрацію і пришвидшує епітелізацію ран. Біологічна активність змінних магнітних полів зумовлена також й індукованими в організмі електричними полями і струмами. В результаті збільшується швидкість проведення потенціалів дії по нервових провідниках і зменшується периневральний набряк. Відновлення фрункціональних властивостей нейролеми аферентних провідників больової чутливості спричинює ослаблення, а потім і припинення імпульсації з больового вогнища. За рахунок збільшення коливальних рухів фрормених елементів і білків плазми крові під впливом низькочастотного магнітного поля відбувається активація локального кровотоку і посилення кровопостачання різних органів і тканин. Відновлення порушеного локального кровотоку в багатьох випадках становить основу клінічної ефективності цього чинника. Низькочастотні магнітні поля підсилюють утворення рилізинг-сракторів у гіпоталамусі і тропних гормонів гіпофріза, які стимулюють функцію надниркових залоз, щитоподібної залози, статевих органів та інших ендокринних залоз. У результаті фрормуються загальні пристосувальні реакції організму, спрямовані на підвищення його резистентності й толерантності до фрізичних навантажень. Крім того, активація низькочастотними магнітними полями центральних ланок нейроендокринної регуляції діяльності внутрішніх органів зумовлює посилення в них переважно катаболічних реакцій. За рахунок розслаблення гладких м'язів периферичних судин такі поля мають слабку гіпотензивну дію. Лікувальні ефректи низькочастотного магнітного поля: судинорозширювальний, катаболічний, протизапальний, ангіопротекторний, трофічний, гіпокоагулювальний, гіпотензивний [8-10].

В огляді [11] здійснено аналіз наукових публікацій, присвячених впливу електромагнітних полів (ЕМП) на різні системи організму людини і тварин із пухлинами. Висвітлюються теоретичні основи й результати практичного використання ЕМП в різних модуляціях для завдань онкології, у тому числі для оптимізації процесу знеболювання й корекції життєдіяльності організму з пухлиною. Подано відомості про можливі еоректи, особливості, механізми лікувального впливу. Висвітлено здатність ЕМП до переносу інорормації як всередині однієї біосистеми, так і на рівні цілого живого організму з пухлиною.

Проаналізовано дослідження комбінованої дії ЕМП і хіміотерапії. Показано роль ЕМП в індукції апоптозу в клітинах пухлини. Виявлено, що хіміо- 
терапія спільно з ЕМП індукує апоптоз і пригнічує синтез ДНК у клітинах остеосаркоми, раку молочної залози, меланоми та інших пухлин. Досліджено роль ЕМП у посиленні протибольового есректу в організмі онкохворих. Знеболювальний ефект зумовлений припиненням або ослабленням нервової імпульсації з больового вогнища внаслідок усунення гіпоксії, покращення мікроциркуляції, зниження набряків. В якості знеболювального інструменту в онконеврології використовується транскраніальна магнітна терапія. Протибольовий ефект зумовлений стимуляцією антиноцицептивної системи, збільшенням синтезу ендорорінів із подальшим їх викидом у кров.

Нейрофрізіологічні дослідження дають підстави вважати, що дія електромагнітних випромінювань у лікуванні онкологічних хворих пов'язана 3 розвитком реакцій, які сприятливо впливають на сон, емоційний стан, психічний стрес, больовий синдром і загальний стан хворого. У монографії досить переконливо показано різноманіття біологічних ефектів ЕМП [12].

Робота [13] свідчить про вдалу спробу виявити чутливість окремих систем біооб'єктів до ЕМП на рівні 0,2-0,4 нТл. Всі ці відомості дали поштовх до розвитку магнітотерапії. У своїй монографрії автор подає приклади користі магнітотерапії у відновлювальному лікуванні, у тому числі онкологічних хворих, для нормалізації показників крові, ліквідації післяопераційних ускладнень, прискорення репаративних процесів, зняття вираженого больового синдрому.

Крім того, у роботі доведено, що залежно від режимів ЕМП можна отримати стимуляцію або пригнічення швидкості синтезу й часу подвоєння клітин лімфоми людини лінії U937 і меланоми В16 [14]. Гальмування або стимуляція спостережуваних ефектів носила нелінійний характер, що дозволило авторам висловити припущення про існування в тому числі і резонансного механізму відповіді пухлинних клітин на вплив ЕМП, поданого в різних режимах. Відповідно до цієї теорії, під впливом ЕМП відбувається зміна концентрації іонів $\mathrm{Ca}^{2+}, \mathrm{K}^{+}$i $\mathrm{Mg}^{2+}$ у поза- і внутрішньоклітинних середовищах, викликаючи ефрект параметричного резонансу для цих іонів у біологічній системі, який збігався з їхньою іонною циклотронною частотою. У результаті виниклий трансмембранний струм у режимі параметричного резонансу буде мінятися не лінійно, а стрибкоподібно, що і пояснює рівень чутливості пухлинної клітини до цього фрізичного чинника.

Крім того, автор зазначає зміну активності мембранних фрерментів і регуляторних білків, що впливають на швидкість залежних від них біохімічних реакцій у клітині. Таким чином, можна констатувати ефекти параметричного резонансного впливу ЕМП на трансмембранний струм іонів і активність мембранних фрерментів, що впливають на мітотичну активність, на синтез ДНК та модулюючих процеси передачі сигналу.

В огляді В. С. Улащик детально висвітлив передбачувані механізми фрізіологічної та лікувальної дії ЕМП [15]. Автор робить висновок, що дія ЕМП реалізується завдяки різним первинним фрізико-хімічним процесам, що відбуваються в біологічних структурах на всіх рівнях організації після такого впливу. Подано відомості про особливості та механізми впливу цього фрактора на органи й системи організму й різноманітність терапевтичних ефектів, що визначають широкі показання до лікувально-профрілактичного використання магнітотерапії в клінічній медицині. Аналіз наукової літератури свідчить, що особливий інтерес представляє метод загального впливу вихрового магнітного поля - оцінено ефективність його застосування в лікуванні пухлинних захворювань. Загальним висновком є відсутність будь-яких ознак пошкодження здорових тканин і пригнічення фрункцій імунної та кровотворної систем, що дозволяє рекомендувати застосування в різних схемах перед- i післяопераційного лікування онкологічних хворих.

Вивчення стану імунної системи хворих на рак молочної залози II-III стадій у ході комплексного лікування із застосуванням магнітотерапії показало, що її дія спричиняє активізацію Т-клітинної ланки імунної системи і сприяє зниженню шкідливої дії опромінення на імунокомпетентні клітини. Змінювалося співвідношення хелперно-супресорних фрракцій Т-лімфоцитів на користь Т-хелперів, що є позитивним моментом перед оперативним втручанням у ході системної хіміотерапії.

Автори дійшли висновку, що ЕМП пригнічує ріст остеосаркоми, індукує апоптоз і впливає на метаболізм кісткової тканини через активацію OPG. $€$ підстави вважати, що застосування ЕМП у визначених режимах може бути корисним під час терапії метастатичних пухлин кісток, так як ці поля здатні викликати остеобластичні диференціювання без проліферації пухлинних клітин. У подальших дослідженнях було доведено, що хіміотерапія із застосуванням магнітних полів здатна індукувати апоптоз у різних пухлинних тканинах, таких як остеосаркома, рак молочної залози, рак шлунка, рак товстої кишки і меланома [16]. Також показано, що пряма дія ЕМП на культивовані in vitro пухлинні клітини не тільки індукує процеси апоптозу, а й пригнічує в них синтез ДНК до $30 \%$.

У статті [10] здійснено огляд результатів дослідження дії як потужних (1200 мТл), так і слабких (5-100 мТл) низькочастотних магнітних полів на ріст, морфологію пухлин, тривалість життя і виживання тварин із саркомою М-1, альвеолярним раком печінки PC-1 і карциномою Ерліха. Наявні у праці експериментальні дані уможливлюють висновок, що магнітні поля, застосовувані в різних параметрах і режимах, здатні володіти протипухлинною дією
ISSN 2706-6282(print)

ISSN 2706-6290(online)
Вісник медичних і біологічних досліджень Bulletin of Medical and Biological Research
$4(10), 2021$ 
і здійснювати модулюючий вплив на підвищення есрективності основних засобів протипухлинної терапії злоякісних новоутворень. Протипухлинний ефрект залежить від параметрів (частота, потужність) й умов застосування цього фрізіотерапевтичного фрактора.

Таким чином, обґрунтуванням до застосування низькочастотного магнітного поля $є$ його вплив на збільшення швидкості проведення імпульсів по нервових волокнах, підвищення їхньої збудливості, зменшення периневрального набряку, врегулювання збудливості ЦНС, нормалізація фуннції вегетативної нервової системи, зниження підвищеного тонусу судин, активація локального кровотоку, посилення кровопостачання різних органів і тканин та їхньої трофріки, слабка гіпотензивна дія, нормалізація згортання крові, стимуляція обміну речовин, регенераційних процесів та фрункції ендокринних залоз, імунної системи, індукція апоптозу, протипухлинний вплив.

В дисертаційній роботі [17] обґрунтовано застосування «сухих» вуглекислих ванн та магнітотерапії на санаторному етапі в комплексній програмі реабілітації дітей у періоді ремісії онкологічних захворювань.

Загальний комплекс реабілітації для 37 дітей 3 онкозахворюваннями (О3) містив: щадний руховий режим, кліматотерапію, дієтичне харчування, лікувальну фрізкультуру за методиками у спеціальних медичних групах для дітей із різними соматичними захворюваннями, синглетно-кисневий коктейль, дитячий фріточай (холосас із аскорбіновою кислотою), програми психологічної допомоги хворим дітям і їх батькам [18, 19].

Реабілітаційний комплекс № 1 (PК 1) - для 25 дітей із супутніми захворюваннями нервової системи у стані ремісії онкогематологічних захворювань (17 осіб) та солідних пухлин (8 осіб) у періоді ремісії більше п'яти років додатково призначали магнітотерапію на шийно-комірцеву зону за такою методикою: магнітна індукція 20-30 мТл, експозиція 10-15 хв, через добу, на курс п'ять процедур.

Реабілітаційний комплекс № 2 (РК 2) - для 45 дітей із супутніми захворюваннями серцево-судинної та нервової системи в періоді ремісії онкогематологічних захворювань (34 осіб) та солідних пухлин (11 осіб) додатково призначали «сухі» вуглекислі ванни на верхні та нижні кінцівки за такою методикою. Через добу застосовували «сухі» вуглекислі ванни на верхні та нижні кінцівки за визначеним розкладом: у періоді ремісії від трьох до п'яти років швидкість потоку вуглекислого газу 15-20 л/хв, температура газової суміші $-37-38^{\circ} \mathrm{C}$, концентрація $\mathrm{CO}_{2}$ процедури № 1-3 - 10 \%, процедури № 4-7 - $15 \%$ тривалістю 15 хв.; у періоді ремісії більше п'яти років тривалість курсу становить до 10 процедур, з підвищенням концентрації $\mathrm{CO}_{2}$ у процедурах № 8-10 до 20 \%, тривалість процедури - 15 хв. Патент № 88912.

Отримано наступні результати [20-31].

Застосування комплексу СКР із додатковим призначенням магнітотерапії (PK 1) дозволило достовірно зменшити скарги дітей у періоді ремісії О3 із супутніми захворюваннями нервової системи. Показники УЗДГ уможливили встановлення позитивних змін мозкової гемодинаміки: зменшення церебральної ангіодистонії в 1,7 ( $<<0,05)$, асиметрії кровообігу - в 1,8 ( $<<0,05)$ та венозної дисгемії - в $1,8$ ( $p<0,05)$, підвищення резерву кровообігу - в 2 $(p<0,05)$ та покращання адаптаційних можливостей апарату ауторегуляції мозкового кровообігу - в 1,9 раза $(\mathrm{p}<0,05)$. Результати ультразвукової ЕхоЕГ свідчили про покращання ліквородинаміки: зменшення явищ внутрішньочерепної гіпертензії - в 2,2 ( $p<0,05)$ та частоти реєстрації додаткових ехо-сигналів - в 4 $(p<0,05)$, ознак гіпертензійно-лікворного синдрому - у 2 та індексу пульсації - у 3 рази. Використання ЕЕГ уможливило встановлення позитивних зміни електрогенезу з нормалізацією біоелектричної активності - в 1,9 ( $p<0,05)$ та статистично достовірним покращанням функціональної активності кори головного мозку - в 2,1 раза $(p<0,05)$.

Після лікування дітей у стані ремісії онкозахворювань із супутньою патологією серцево-судинної та нервової систем із додатковим застосуванням «сухих» вуглекислих ванн на верхні та нижні кінцівки (РК 2) встановлено поліпшення клініко-неврологічного стану та самопочуття: зменшення частоти головного болю $(p<0,001)$, дратівливості $(p<0,001)$, стомлюваності ( $<<0,001)$, ознак астеноневротичного та вегетосудинного синдромів, церебросудинної недостатності. Наприкінці санаторно-курортної реабілітації також відзначали позитивну динаміку за показниками, які характеризують мозковий кровообіг, біоелектричну активність головного мозку та ліквородинаміку.

Так, під впливом «сухих» вуглекислих ванн зменшилися вияви церебральної ангіодистонії - в 1,8 ( $p<0,01)$, венозної дисгемії - у 2 ( $p<0,001)$, асиметрії кровообігу - в 1,9 ( $p<0,001)$, підвищилися резерв кровообігу - в 2 ( $p<0,001)$ та адаптаційні здатності апарату ауторегуляції - в 1,9 раза $(p<0,01)$. За даними ультразвукової ехоенцефалографрії, зменшилися явища внутрішньочерепної гіпертензії - у 2 ( $p<0,001)$, вияви гіпертензійно-лікворного синдрому - у 2 ( $<<0,05)$, виявлення додаткових ехо-сигналів у 2,7 ( $p<0,05)$, знизився індекс пульсацій - у 3 рази $(p<0,05)$. Поряд із цим, у дітей у стані ремісії О3 під впливом РК 7 реєстрували позитивну динаміку біоелектричної активності кори головного мозку, а саме покращання електрогенезу - у 2 ( $p<0,01)$ та підвищення функціональної активності - у 2,2 раза $(p<0,001)$, що підтверджує регулювальний (оптимізуючий) вплив «сухих» вуглекислих ванн 
на кровообіг, ліквородинаміку та біоелектричну активність мозку.

Зважаючи на отримані результати, необхідно вважати за доцільне продовження досліджень впливу фрізичних (природних та преформованих) фракторів на есрективність санаторно-курортної реабілітації онкохворих дітей.

\section{ВИСНОВКИ}

1. Застосування лікувального комплексу з додатковим призначенням магнітотерапії (РК1) дозволяє вірогідно зменшити скарги дітей у періоді ремісії О3 із супутніми захворюваннями нервової системи. За показниками УЗДГ встановлено статистично вірогідні позитивні зміни мозкової гемодинаміки. Результати УЗ ЕхоЕГ свідчать про покращання ліквородинаміки. За даними ЕЕГ встановлено позитивні зміни в стані електрогенезу головного мозку.
2. Після проведеного лікувального комплексу з додатковим призначенням «сухих» вуглекислих ванн (РК2) покращилося самопочуття дітей. За показниками ультразвукової доплерографії у 70,0% дітей нормалізувався кровообіг по церебральних артеріях. Венозна дисгемія реєструвалась удвічі рідше порівняно з вихідними даними. Венозний застій III ст. не реєструвався Частота виявлення внутрішньочерепної гіпертензії зменшилася з 90,0 до 50,0 \%. За показниками ультразвукової ехоенцефалографрії відмічалося покращення ліквородинаміки у вигляді зменшення індексу пульсації вдвічі та частоти реєстрації додаткових Ехо-сигналів більш ніж утричі у 70,0 \% хворих дітей. Стан електрогенезу характеризувався нормалізацією біоелектричної активності головного мозку, що супроводжувалося стабілізацією фрункціональної активності кори у 70,0 \% дітей.

\section{СПИСОК ЛІТЕРАТУРИ}

1. Кармазина И. В. Роль природных фризических фракторов в восстановлении здоровья детей с онкопатологией : научно-практическая консреренция с международным участием, посвященная 150-летию со дня рождения профрессора А. Е. Щербака «Актуальные вопросы курортологии, фризиотерапии и медицинской реабилитации» (Ялта, 2013 г.) / И. В. Кармазина, Е. М. Мельцева // Труды КРУ «НИИ им. И. М. Сеченова». - 2013. - T. XXIV. - C. 191.

2. Кенц В. В. Физиотерапия и курортная реабилитация онкологических больных. Медицинская реабилитация, курортология, фризиотерапия / В. В. Кенц, Е. О. Косоверов, А. В. Паненко // Российский журнал физиотерапии, курортологии и реабилитации. - 2005. № 4. - С. 32-35.

3. Польщакова Т. В. Доцільність ранньої реабілітації дітей з онкологічними захворюваннями за поліклінічних умов / Т. В. Польщакова // Мед. реабілітація, курортологія, фрізіотерапія. - 2010. - № 1. - С. 8-11.

4. Бородулін С. Д. Комплексне застосування лікувальних газових «сухих» вуглекислих ванн, камер та фрізіотерапевтичних процедур: метод. рекомендації / С. Д. Бородулін, І. В. Галіна, В. Д. Неробєєв. - Одеса, 2001. - 27 c.

5. Аджимамудова И. В. Сухие углекислые ванны в терапии бронхиальной астмы у детей : автореферат дисс. на соискание науч. степени канд. мед. наук / Ирина Валериевна Аджимамудова. - М., 2002. - 25 с.

6. Рау И. В. Влияние «сухих» и водных углекислых ванн на регионарное кровообращение и метаболические процессы у больных десрормирующим остеоартрозом: автореферат дисс. на соискание науч. степени канд. мед. наук / И. В. Рау. - М., 1988. - 22 с.

7. Персиянова-Дурнова А. Л. Влияние углекислых ванн и фризических тренировок на внутрисердечную гемодинамику и процессы ремоделирования у больных постинорарктным кардиосклерозом с нарушенной фрункцией левого желудочка автореферат дисс. на соискание науч. степени канд. мед. наук / Анна Леонидовна Персиянова-Дурнова. - М., 2003. - 19 с.

8. Пономаренко Г. Н. Физические методы лечения: справочник / Г. Н. Пономаренко. - СПб. : ВМедА, 2002. -299 c.

9. Грушина Т. И. Реабилитация в онкологии: фризиотерапия / Т. И. Грушина. - М. : ГЕОТАР-Медиа, 2006. $-240 \mathrm{c}$.

10. Улащик В. С. Некоторые итоги исследования противоопухолевого действия магнитных полей в эксперименте / В. С. Улащик // Вопросы курортологии, фризиотерапии и лечебной фризической культуры. - 2015. - № 92 (4). - С. 48-53.

11. Франциянц Е. М. Противоопухолевое действие электромагнитных полей и их влияние на боль В экспериментальной и клинической онкологии / Е. М. Франциянц, Е. М. Шейко // Исследования и практика в медицине. - 2019. - № 6 (2). - С. 99-86.

12. Плеханов Г. Б. Основные закономерности низкочастотной электромагнитобиологии / Г. Б. Плеханов. Томск: Изд-во Томского ун-та, 1990. - 188 с.

13. Темурьянц Н. А. Сверхнизкочастотые электромагнитные сигналы в биологическом мире / Н. А. Темурьянц, Б. М. Владимирский, О. Г. Тишкин. - К. : Наукова думка, 1992. - 187 с.

14. Реакция опухолевых клеток на воздействие низкочасттных низкоинтесивных ЭМП / Д. Ю. Сахаров, Г. Ледницкий, С. Д. Казьмин [и др.] // Экспериментальная онкология. - 1996. - Т. 18. - С. 178-184.

15. Улащик В. С. Магнитотерапия: современные представления о механизмах действия магнитных полей на организм / В. С. Улащик // Здравоохранение. 2015. - № 11. - C. 21-29.

16. Low intensity and frequency pulsed electromagnetic fields selectively impair breast cancer cell viability / S. Crocetti, C. Beyer, G. Schade [et al.] // PLoS One. - 2013. - Vol. 8 (9). - e72944. DOI: 10.1371/journal. pone.0072944.
$4(10), 2021$ 
17. Шаповалова Г. А. Санаторно-курортна реабілітація дітей в стадії ремісії онкозахворювань: обґрунтування диореренційованих програм з урахуванням супутньої патології: авторефр. дис. ... докт. мед. наук. 14.01.33 медична реабілітація, фрізіотерапія та курортологія 222 медицина. - Харківська медична академія післядипломної освіти. - Харків, 2021. - 41 с.

18. Venger O. Psychological and psychopathological features of patients with skin cancer / O. Venger, I. Zhulkevych, Yu. Mysula // Georgian Medical News. 2021. - Vol. 315 (6). - P. 29-33.

19. Кривоніс Т. Г. Гендерні особливості прояву клініко-психологічних феноменів у онкологічних пацієнтів / Т. Г. Кривоніс, И. В. Жулкевич // Здобутки клінічної і експериментальної медицини. - 2020. - № 1. - С. 115-119. DOI: 10.11603/1811-2471.2020.v.i1.11078.

20. Поберская В. А. Научное обоснование применения фризических фракторов на этапе реабилитации детей, перенесших онкологические заболевания / В. А. Поберская, А. А. Шаповалова, А. В. Макаренко // Міжнародний журнал «Реабілітація та паліативна медицина». - 2015. - № 1 (1). - С. 37-41.

21. Польщакова Т. В., Шаповалова Г. А., Кубиніна Л. В., Лукаш О. В. Застосування «сухих» вуглекислих ванн у санаторно-курортній реабілітації дітей в періоді ремісії онкологічних захворювань / Т. В. Польщакова, Г.А.Шаповалова, Л. В. Кубиніна, О.В.Лукаш // Медична реабілітація, курортологія, фрізіотерапія. - 2015. - № 1. C. $29-33$

22. Шаповалова Г. А. Динаміка клінічних та клінікоінструментальних показників у дітей з супутніми захворюваннями нервової системи в періоді ремісії онкозахворювань із додатковим призначенням магнітотерапії / Г. А. Шаповалова, К. Д. Бабов // Здобутки клінічної та експериментальної медицини. - 2018. - № 2. - С. 207210.

23. Шаповалова Г. А. Обґрунтування способу санаторно-курортної реабілітації дітей з онкогематологічними захворюваннями / Г. А. Шаповалова, Т. В. Польщакова // Український журнал біології, медицини і спорту. - 2018. - Т. 3, № 5 (14). - С. 194-197.

24. Шаповалова Г. А. Застосування «сухих» вуглекислих ванн в комплексі реабілітації дітей з супутніми ураженнями нервової системи в періоді ремісії онкозахворювань / Г. А. Шаповалова // Зб. наук. праць співробітників НМАПО ім. П. Л. Шупика. - 2014. - Вип. 23, KH. 3. - C. 375-381.

25. Шаповалова Г. А. Наукове обґрунтування застосування «сухих» вуглекислих ванн у комплексі реабілі- тації дітей із супутньою патологією неровової системи в періоді ремісії онкозахворювань. Актуальні питання діагностики та лікування захворювань нервової системи: матеріали наук.-практ. конфр. $з$ міжнар. участю (Київ, 12-13 жовт. 2017 р.) / Г. А. Шаповалова, Т. В. Польщакова // Український неврологічний журнал. - 2017. № 3. - C. 64.

26. Шаповалова А. А. Научное обоснование применения «сухих» углекислых ванн в комплексе реабилитации детей с сопутствующими поражениями нервной системы в периоде ремиссии онкогематологических заболеваний: материали наук.-практ. коно., присвяченної дню народження шановного Маммадкаріма оглу Алієва (Баку, 2018 г.) / А. А. Шаповалова. - Баку, 2018. C. $410-412$.

27. Шаповалова Г. А. Магнітотерапія як складова комплексу санаторно-курортної реабілітації дітей з супутніми захворюваннями нервової системи в періоді ремісії онкозахворювань / Г. А. Шаповалова // Впровадження сучасних досягнень медичної науки у практику охорони здоров'я України: матеріали VII Міжнар. медичного конгресу (Київ, 25-27 квіт. 2018 р.). - К. : Міжнародний медичний конгрес, 2018. - С. 56.

28. Диференційоване застосування «сухих» вуглекислих ванн у санаторно-курортній реабілітації дітей після лікування онкогематологічних захворювань та злоякісних новоутворень: методичні рекомендації / В. О. Поберська, Т. В. Польщакова, Г. А. Шаповалова [та iн.]. - K., 2014. -22 c.

29. Поберська В. О. Застосування 4-камерних «сухих» вуглекислих ванн у санаторно-курортній реабілітації дітей 3 онкогематологічними захворюваннями: інформаційний лист № 267-2014 / В. О. Поберська, Г. А. Шаповалова, Т. В. Польщакова. - К., 2014. - 4 с.

30. Пат. на корисну модель № 88912 UA, МПК (2006.01) А 61 Н 33/14. Спосіб санаторно-курортної реабілітації дітей з онкогематологічними захворюваннями / В. О. Поберська, Т. В. Шаповалова, Т. В. Польщакова винахідники ; заявник та патентовласник Український науково-дослідний інститут медичної реабілітації та курортології. - № u 201310672 ; заявл. 04.09.2013 ; опубл. 10.04.2014, Бюл. № 7. - 9 с.

31. Substantiation of the additional prescription of magnetotherapy in the complex of rehabilitation of children with concomitant diseases of the nervous system during remission of cancer / $\mathrm{H}$. Shapovalova, I. Shmakova A. Mokiienko [et al.] // Balneo and PRM Res. J. - 2021. Vol.12 (1). - P. 73-76. - Access mode : https://repo.odmu. edu.ua:443/xmlui/handle/123456789/10058.

\section{REFERENCES}

1. Karmazina IV, Meltseva EM. [The role of natural physical factors in restoring the health of children with oncopathology]. Proceedings of the scientific and practical conference with international participation, dedicated to the 150th anniversary of the birth of professor A. Ye. Shcherbak "Topical issues of balneology, physiotherapy and medical rehabilitation". I.M. Sechenov Research Institute. 2013;XXIV:191. Russian.
2. Kents VV, Kosoverov EO, Panenko AV. [Physiotherapy and spa rehabilitation of cancer patients. Medical rehabilitation, balneology, physiotherapy]. Russ zhurn psikorer balneol reab. 2005;4:32-35. Russian.

3. Polschakova TV. [Expediency of early rehabilitation of children with oncological diseases under outpatient conditions]. Med reab balneol pysiot. 2010;1: 8-11. Ukrainian. 
4. Borodulin SD, Galina IV, Nerobeev VD. Complex application of therapeutic gas "dry" carbon dioxide baths, chambers and physiotherapeutic procedures: method. recommendations. [Комплексне застосування лікувальних газових «сухих» вуглекислих ванн, камер та фрізіотерапевтичних процедур: метод. рекомендації] Odesa; 2001. Ukrainian.

5. Adzhimamudova IV. [Dry carbon dioxide baths in the treatment of bronchial asthma in children]. Extended abstract of candidate's thesis. Moscow; 2002. Russian.

6. Rau IV. [Influence of "dry" and water carbon dioxide baths on regional blood circulation and metabolic processes in patients with deforming osteoarthritis]. Extended abstract of candidate's thesis. Moscow; 1988. Russian.

7. Persiyanova-Durnova AL. [Effect of carbon dioxide baths and physical training on intracardiac hemodynamics and remodeling processes in patients with postinfarction cardiosclerosis with impaired left ventricular function]. Extended abstract of candidate's thesis. Moscow; 2003. Russian.

8. Ponomarenko GN. Physical methods of treatment: a reference book. [Физические методы лечения: справочник] Saint-Petersburg: VMedA; 2002. Russian.

9. Grushina TI. Rehabilitation in oncology: physiotherapy. [Реабилитация в онкологии: фризиотерапия] Moscow: GEOTAR-Media; 2006. Russian.

10. Ulashchik VS. [Some results of the study of the antitumor effect of magnetic fields in the experiment]. Voprosy kurortologii, fizioterapii i lechebnoy fizicheskoy kultury. 2015;92(4): 48-53. Russian.

11. Frantsiyants EM, Sheiko EM. [Antitumor effect of electromagnetic fields and their effect on pain in experimental and clinical oncology]. Issledovaniya i praktika v meditsine. 2019;6(2): 99-86. Russian.

12. Plekhanov GB. Basic laws of low-frequency electromagnetobiology. [Основные закономерности низкочастотной электромагнитобиологии] Tomsk: Izdatelstvo Tomskoho Universiteta; 1990. Russian.

13. Temuryants NA. Ultra-low-frequency electromagnetic signals in the biological world. [Сверхнизкочастотые электромагнитные сигналы в биологическом мире] Kyіv: Naukova Dumka; 1992. Ukrainian.

14. Sakharov DYu, Lednitskiy G, Kazmin SD. [The reaction of tumor cells to the effect of low-frequency lowintensity EMF]. Eksp onkol. 1996;18:178-84. Russian.

15. Ulashchik VS. [Magnetotherapy: modern ideas about the mechanisms of action of magnetic fields on the body]. Zdravokhraneniye. 2015;11: 21-9. Russian.

16. Crocetti S, Beyer C, Schade G, Egli M, Frohlich J, Franco-Obregon A. Low intensity and frequency pulsed electromagnetic fields selectively impair breast cancer cell viability. PLoS One. 2013;8(9): e72944. DOI: 10.1371/journal. pone.0072944.

17. Shapovalova GA. [Sanatorium-and-spa rehabilitation of children in the stage of remission of oncological diseases: substantiation of differentiated programs taking into account concomitant pathology]. Extended abstract of candidate's thesis. Kharkiv: Kharkivska medychna akademiia pisliadyplomnoi osvity; 2021. Ukrainian.

18. Venger O, Zhulkevych I, Mysula Yu. Psychological and psychopathological features of patients with skin cancer. Georgian Medical News. 2021;315(6): 29-33.
19. Krivonis TG, Zhulkevych IV. [Gender features of clinical-psychological phenomena in cancer patients]. Zdobutky klinichnoi i eksperymentalnoi medytsyny. 2020;1: 115-9. DOI: 10.11603/1811-2471.2020.v.i1.11078. Ukrainian.

20. Poberskaya VA, Shapovalova AA, Makarenko AV. [The sci entific gro und of use of physical fac tor $s$ on the stage of rehabili tatio $\mathrm{n}$ of childr en who had oncolo gic di seases]. Mizhnarodnyi zhurnal «Reabilitatsiia ta paliatyvna medytsyna». 2015;1(1): 37-41. DOI 10.15574/ IJRPM.2015.01.37. Russian.

21. Polschakova TV, Shapovalova GA, Kubinina LV, Lukash OV. [Application of "dry" carbon dioxide baths in sanatorium rehabilitation of children in the period of remission of oncological diseases]. Medychna reabilitatsiia, kurortolohiia, fizioterapiia. 2015;1: 29-33. Ukrainian.

22. Shapovalova AA, Babov KD. [Dynamics of clinical and clinical-instrumental indices in children with accompanying diseases of the nervous system in the period of remission of cancer with additional administration of magnetotherapy]. Zdobutky klinichnoi i eksperymentalnoi medytsyny. 2018;2: 207-10. DOI: 10.11603/1811-2471.2018. v0.i2.8927. Ukrainian.

23. Shapovalova GA, Polschakova TV. [Substantiation of the method of sanatorium-resort rehabilitation of children with oncohematological diseases]. Ukr zhurn biol med sport. 2018;3(5(14)): 194-7. Ukrainian.

24. Shapovalova GA. [The use of "dry" carbon dioxide baths in the complex of rehabilitation of children with concomitant lesions of the nervous system in the period of remission of cancer]. Collection of scientific works of staff member of P. L. Shupyk NMAPE. 2014;23(3): 375-81. Ukrainian.

25. Shapovalova GA, Polschakova TV. [Scientific substantiation of the use of "dry" carbon dioxide baths in the rehabilitation complex of children with concomitant pathology of the nervous system in the period of remission of cancer]. Proceedings of the International Conference: "Topical issues of diagnosis and treatment of diseases of the nervous system". (October 12-13 Kyiv, 2017). Ukrainskyi nevrolohichnyi zhurnal. 2017;3: 64. Ukrainian.

26. Shapovalova AA. [Scientific substantiation of the use of "dry" carbon dioxide baths in the complex of rehabilitation of children with concomitant lesions of the nervous system in the period of remission of oncohematological diseases]. Proceedings of the Science Conference dedicated to the Day of the People's Day of Mammadkarim oglu Aliyev (Baku, 2018). Baku; 2018. Russian.

27. Shapovalova GA. [Magnetotherapy as a component of the complex of sanatorium rehabilitation of children with concomitant diseases of the nervous system in the period of remission of cancer]. Proceedings of the VII International Medical Congress: Introduction of modern achievements of medical science in the practice of health care Ukraine. (April 25-27 Kyiv, 2018). Kyiv: Mizhnarodnyi medychnyi konhres; 2018. Ukrainian.

28. Kubynina LV, Makarenko AV, Panenko AV, Poberska VO, Polshchakova TV, Shapovalova HA, Yanchenko TS. [Differentiated use of "dry" carbon dioxide baths in sanatorium rehabilitation of children after treatment of oncohematological diseases and malignant neoplasms]. Kyiv; 2014. Ukrainian.

29. Poberska VO, Shapovalova GA, Polschakova TV.
ISSN 2706-6282(print)

ISSN 2706-6290(online) 
[Application of 4-chamber "dry" carbon dioxide baths in sanatorium rehabilitation of children with oncohematological diseases]. Informatsiynyi lyst № 267-2014. Kyiv; 2014. Ukrainian.

30. Pat. Ukraine for utility model No. 88912 UA, (2006.01) A 61 H 33/14. Poberska VO, Shapovalova GA, Polschakova TV, inventors; "Ukrainian Research Institute of Medical Rehabilitation and Resort Therapy of the Ministry of Health of Ukraine". [Method of sanatorium rehabilitation of children with oncohematological diseases]. No. u 2013 10672. 2014 Apr 10, Bull. No. 7. Ukrainian.

31. Shapovalova H, Shmakova I, Mokiienko A, Gushcha S, Plakida A. Substantiation of the additional prescription of magnetotherapy in the complex of rehabilitation of children with concomitant diseases of the nervous system during remission of cancer. Balneo PRM Res J. 2021;12(1): 736. Available from: https://repo.odmu.edu.ua:443/xmlui/ handle/123456789/10058. 